\title{
An application of organizational excellence assessment: Evidence from cement industry
}

\author{
Hadi Pazoki Toroudi ${ }^{*}$, Sarineh Naderi Alamdardehi ${ }^{\mathrm{b}}$, Nasim Mahjoub ${ }^{\mathrm{b}}$ and Alireza Sheydaei \\ Ardestani $^{\text {b }}$
}

${ }^{a}$ Manager, Department of Industrial Engineering, Tajan University, Ghaemshar , Iran

${ }^{b}$ Bachelor of Industrial Engineering, Tajan University, Ghaemshar , Iran

\begin{tabular}{l}
\hline C H R O N I C L E \\
\hline Article history: \\
Received March 25, 2015 \\
Received in revised format \\
August 162015 \\
Accepted September 302015 \\
Available online \\
October 32015 \\
\hline Keywords: \\
EFQM \\
Organizational Excellency model \\
Organizational evaluation \\
Cement factory
\end{tabular}
\begin{abstract}
A B S T R A C T
The objective of this paper is to evaluate the performance of Kiasar cement factory based on EFQM model. The study performs a survey among 26 managers and expertise and the required information is gathered in terms of five perspectives based on 23 questions arranged in Likert spectrum. Cronbakh's $\alpha$ coefficient for enabling and results criteria are 0.924 and 0.950 , respectively, which confirms the reliability of the questionnaire. In evaluating the data, it is revealed that employees' scale, maintained the most difference $(70.61 \%)$ and processes scale, retained the least difference (52.42\%) from the ideal circumstances. Next, employees' performance has maintained the most difference $(90.79 \%)$ and customer performance, and the customer results' scale have kept the least difference (58.27\%) from the ideal situation. Kiasar cement factory has acquired 198.06 points out of 500 points of empowering scale and 164.08 points out of 500 total points of result scales. Also empowerment scales in Kiasar cement factory have acquired $39.61 \%$ of optimal score and differs from ideal circumstances around $60.39 \%$. The results scales has acquired $32.82 \%$ of optimal score and approximately is different from ideal situation around $67.18 \%$. The research results show that Kiasar cement factory has acquired 361.9 points out of 500 scores of EFQM.
\end{abstract}

\section{Introduction}

One of the concerns in any firm is to measure the performance of an organization and there are various techniques to determine firms' success in terms of customer satisfaction, quality of services, etc. The European Foundation for Quality Management (EFQM) (2013) excellence model is a non-prescriptive framework for organizational management systems to help firms become more competitive (Shaw, 2000; Bou-Llusar et al., 2009; Zárraga-Rodríguez \& Álvarez, 2014). The EFQM Model presents a model helping organizations determine their current "level of excellence". They also learn on where to focus their improvement efforts. Besides, the framework helps to make sure that business decisions include the necessities of all stakeholders and are aligned with the firm's objectives. EFQM provides

\footnotetext{
* Corresponding author.

E-mail address: h.pazoki.ums@gmail.com (H. Pazoki Toroudi) 
its users with a set of performance improvement tools to reach and sustain results and excellence and it is reviewed to find new ideas, concepts and learning. EFQM has been extensively used for the past two decades in different industries. Cabrerizo and Pérez (2013), for example, presented a consensus support model for the initial-self assessment of the EFQM in health care firms. Yousefie et al. (2011) presented a technique for selection of effective management tools on setting EFQM model by a quality function deployment (QFD) approach. Wongrassamee et al. (2003) investigated two techniques including Kaplan and Norton's Balanced Scorecard and the EFQM Excellence Model. Each consists of a non-prescriptive template offering managers a small number of groups of key performance metrics to focus on. The analysis reported that despite having some significant differences both techniques seem to be developed from similar concepts. They concluded that it was difficult to determine a perfect match between a company and a performance measurement framework. Hosseini and Aalikhani (2014) investigated the level of customer oriented in an excellence business organization through EFQM method for one of the biggest Iranian banks in city of Tehran, Iran. Abbasi and Farhangi (2013) used EFQM method for broadcasting firm in Iran. Beikzad et al. (2012) performed an empirical study on empowering private bank workers using EFQM. Kazemi et al. (2012) presented a framework for organizational excellence to detect any possible problems in home appliances industry.

EFQM model is an un-administrative model which has consisted of 9 scales. These scales are the heart and core of the model and are the basis for the evaluation of an organization. EFQM model scales are divided in to two groups:

1-Empower makers: These are 5 scales and they are the factors which empower the organization for reaching the best results.

2-Results: These are the results which the best organizations achieve them in different fields and express the achievements resulted from proper implementation of empower makers. Fig. 1 shows the structure of EFQM method.

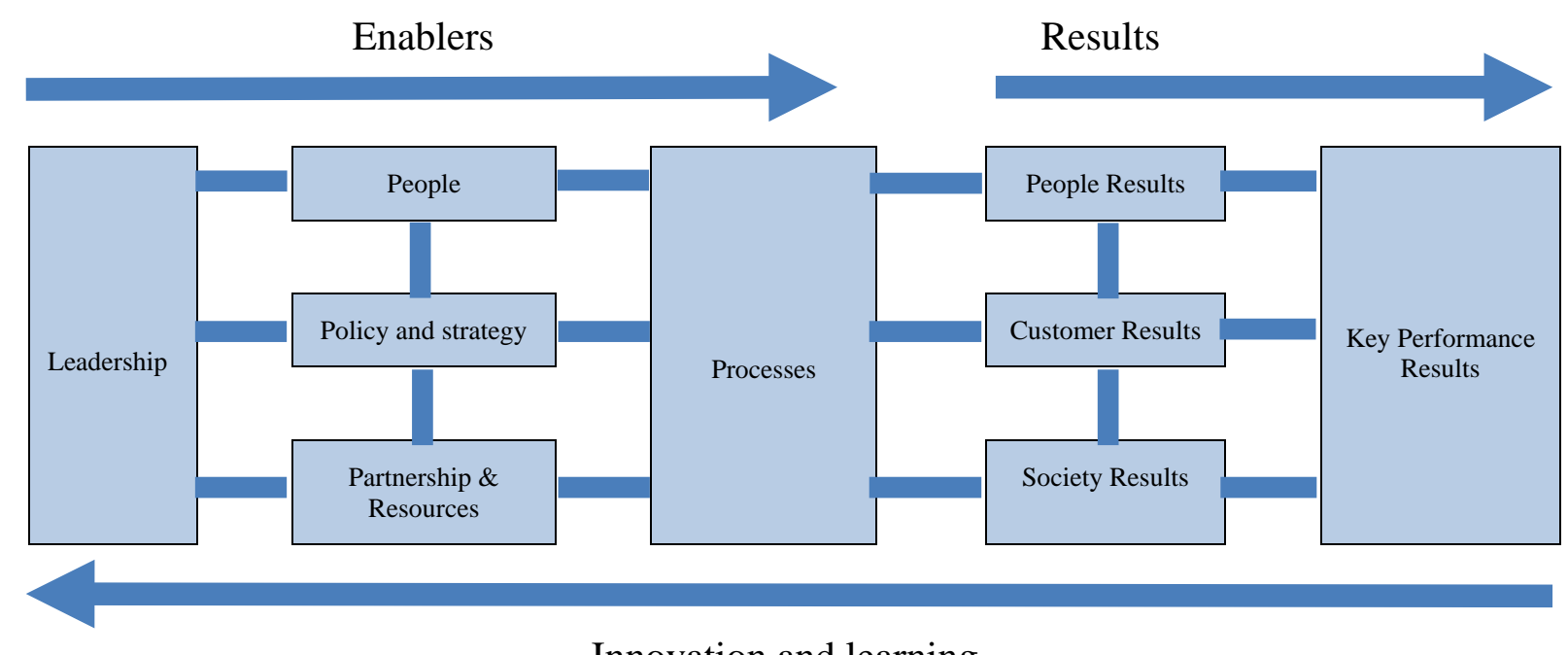

Fig. 1. EFQM transcendent model

According to Fig. 1, leadership is the enabler on processes through people, policy and strategy as well as partnership and \& resources. In addition, designing good processes helps organization reach key performance results through people, customer and society. The key performance results also influence leadership. Next, we present the implementation of EFQM for a cement unit named Kiasar in Iran.

\section{The proposed study}

The objective of this paper is to evaluate the excellency of Kiasar cement factory based on EFQM model. The study performs a survey among 26 managers and expertise and the required information is 
gathered in terms of five perspectives based on 23 questions arranged in Likert spectrum. In order to assess the reliability of the questionnaire in this study, Cronbakh's $\alpha$ coefficient for enabling and results criteria are 0.924 and 0.950 , respectively. The study tries to attempt to determine the amount of leadership, strategy, staff, shareholding as well as resources, process, products and services capabilities in Kiasar cement factory. The study also tries to determine the amount of compliance criteria for the implementation of client, staff, society and key objectives in Kiasar cement factory.

\section{The results}

In this section, we present the results of the implementation of our EFQM questionnaire. Table 1 demonstrates the summary of the results of our survey. The study considers some weights for each scale and the gained scores are multiplied by the relative weights. In addition, the table shows the difference between the gained score and the ideal score.

\section{Table 1}

The summary of the results of the implementation of EFQM method

\begin{tabular}{|c|c|c|c|c|c|c|c|c|}
\hline $\begin{array}{l}\text { distance with } \\
\text { optimal scale }\end{array}$ & $\begin{array}{l}\text { Optimal } \\
\text { distance }\end{array}$ & $\begin{array}{l}\text { score } \\
\text { scale }\end{array}$ & score & $\begin{array}{l}\text { gained } \\
\text { score }\end{array}$ & $\begin{array}{c}\text { weight } \\
\text { coefficient }\end{array}$ & scale & number & rank \\
\hline 61.85 & 61.85 & 100 & 38.15 & 38.15 & 1 & Leadership & $1-1$ & 1 \\
\hline 60.94 & 48.75 & 80 & 31.25 & 39.06 & 0.8 & Strategies & $2-1$ & 2 \\
\hline 70.61 & 63.55 & 80 & 26.45 & 29.38 & 0.9 & Staff & $3-1$ & 3 \\
\hline 61.11 & 55 & 90 & 35 & 38.89 & 0.9 & Resources and & $4-1$ & 4 \\
\hline 52.42 & 73.39 & 140 & 66.61 & 47.58 & 1.4 & Process & $5-1$ & 5 \\
\hline 60.39 & 301.94 & 500 & 198.06 & 36.61 & \multicolumn{2}{|c|}{ Total score of empowering scales } & 1 & \\
\hline 8.27 & 7.44 & 90 & 82.56 & 28.41 & 2 & Customer & $1-2$ & 6 \\
\hline 90.79 & 181.58 & 200 & 18.15 & 20.17 & 0.9 & Staff & $2-2$ & 7 \\
\hline 64.15 & 38.49 & 60 & 21.51 & 35.85 & 0.6 & Society & $3-2$ & 8 \\
\hline 71.85 & 107.78 & 150 & 42.22 & 28.15 & 1.5 & Key performance & $4-2$ & 9 \\
\hline 67.18 & 335.92 & 500 & 164.08 & 32.82 & & & 2 & \\
\hline 63.81 & 638.1 & 1000 & 361.9 & 36.19 & & Total Score & & \\
\hline
\end{tabular}

As we can observe from the results of Table 1, in terms of empowerment perspectives, process has had the minimum distance from the ideal scale followed by leadership, strategies, resources and participation and staff. In addition, customer appears to have the minimum distance from the ideal circumstances (8.27\%) followed by society, staff and key performance criteria.

\section{Conclusion}

Cement industry plays essential role on development of economy and it is important to measure the performance of various cement units and take necessary actions to improve their performances. The present study has implemented an empirical survey on measuring the performance of a cement unit using EFQM method. The results have indicated that the case study of this survey has gained 361.9 out of 1000 points, which means the unit could perform better in case of possible improvement in different perspectives such as leadership, strategies, staff, etc. It has been concluded that employees' scale, maintained the most difference (70.61\%) and processes scale, retained the least difference $(52.42 \%)$ from the ideal circumstances. Next, employees' performance has maintained the most difference (90.79\%) and customer performance, and the customer results' scale have kept the least difference (58.27\%) from the ideal situation. Kiasar cement factory has acquired 198.06 points out of 500 points of empowering scale and 164.08 points out of 500 total points of result scales. Also empowerment scales in Kiasar cement factory have acquired $39.61 \%$ of optimal score and differs from ideal circumstances around $60.39 \%$. The results scales has acquired $32.82 \%$ of optimal score and approximately is different from ideal situation around $67.18 \%$. The research results show that Kiasar cement factory has acquired 361.9 points out of 500 scores of EFQM. 


\section{Acknowledgement}

The authors would like to thank the management team of Kiasar cement factory for their cooperation in accomplishment of this survey. We are also delighted for constructive comments received from the anonymous referees.

\section{References}

Abbasi, M \& Farhangi, A. (2013). An empirical study of implementation of EFQM method for broadcasting organization in Iran. Management Science Letters, 3(3), 961-966.

Beikzad, J., Totakhaneh, Y \& Maleki, S. (2012). An empirical study on empowering private bank workers using EFQM. Management Science Letters, 2(1), 321-328.

Bou-Llusar, J. C., Escrig-Tena, A. B., Roca-Puig, V., \& Beltrán-Martín, I. (2009). An empirical assessment of the EFQM excellence model: evaluation as a TQM framework relative to the MBNQA model. Journal of Operations Management,27(1), 1-22.

Cabrerizo, F. J., \& Pérez, I. J. (2013). A consensus support model based on linguistic information for the initial-self assessment of the EFQM in health care organizations. Expert Systems with Applications, 40(8), 2792-2798.

European Foundation for Quality Management (2013). EFQM Model for Business Excellence. EFQM, Brussels.

Kazemi, S., Nikokar, G., Sadaghiani, J \& Rahimimazraehshahi, M. (2012). Design and explanation of organizational excellence model in home appliances industry. Management Science Letters, 2(1), 403-408.

Hosseini, S. \& Aalikhani, A. (2014). Investigating the level of customer oriented in an excellence business organization through EFQM method. Management Science Letters, 4(11), 2371-2374.

Shaw, C. D. (2000). External quality mechanisms for health care: summary of the ExPeRT project on visitatie, accreditation, EFQM and ISO assessment in European Union countries. International Journal for Quality in Health Care, 12(3), 169-175.

Wongrassamee, S., Simmons, J. E. L., \& Gardiner, P. D. (2003). Performance measurement tools: the Balanced Scorecard and the EFQM Excellence Model. Measuring Business Excellence, 7(1), 14-29.

Yousefie, S., Mohammadi, M., \& Monfared, J. H. (2011). Selection effective management tools on setting European Foundation for Quality Management (EFQM) model by a quality function deployment (QFD) approach. Expert Systems with Applications, 38(8), 9633-9647.

Zárraga-Rodríguez, M., \& Álvarez, M. J. (2014). Does the EFQM Model Identify and Reinforce Information Capability?. Procedia-Social and Behavioral Sciences, 109, 716-721. 